\title{
Integrating National Social Missions and Infrastructure Development in the Indian Context: A New Direction for CSR Expenditure
}

\author{
Prakash Rao, Viraja Bhat, Jeevan Nagarkar
}

\begin{abstract}
Shift in the philosophy of corporate responsibility being voluntary to mandatory has enforced the business organizations to spend $2 \%$ of their average net profit on various community development activities. Across the sectors it can be observed that there has been more emphasis on some select areas such as education and environment. The not so focused and scattered initiatives have resulted in the underutilization of the budgeted CSR across businesses belonging to various sectors. The concept of CSR being seen as a mandate has resulted in the money being spent but not resulting in the outcome which can be seen as sustained activity. Authors in this paper investigated 120 top market cap companies for their CSR expenditure between FY 2014-2015 to FY 2017-2018. CSR funds utilization of these companies was analyzed with respect to 8 designated areas such as education, health and sanitation, environment, women empowerment etc. as per the CSR Act 2013. Data collection for the study is based on the authentic sources such as publicly available annual reports of the companies and Bloomberg. The study discusses the role of these companies with regard to nontargeted CSR budget spending and it's relationship with national Missions/ Policies/ Agenda. With a focused approach and strategy which involves all the stakeholder's involvement, the study proposes a theoretical model for utilization of the CSR funds such as infrastructure building for national missions such as SWACH Bharat, Ayushman Bharat, Smart City Initiatives etc.
\end{abstract}

Keywords : CSR Act, Smart City, SWACHH Bharat, Ayushman Bharat

\section{INTRODUCTION} emerged as a major governance approach amongst business and industry.

The act of giving and philanthropy has been in existence for several decades and often found favour amongst the corporate world as a means to improve societal wellbeing.

Acting responsibly has amongst the corporate world been accepted as an approach to improve and strengthen the overall economic, environmental and social upliftment of society.

The evolution of CSR as a specialised discipline was first contemplated during the decades of 80 s when the world community began to discuss possible inter-disciplinary connects between industry, development and society.

Revised Manuscript Received on September 10, 2019.

Dr. Prakash Rao, Symbiosis Institute of International Business, Symbiosis International University, Pune, Maharshtra, India.

(Email : dydirector@siib.ac.in)

Dr. Viraja Bhat, Symbiosis Institute of International Business,

Symbiosis International University, Pune, Maharshtra, India.

(Email : viraja@siib.ac.in) Symbiosis International University, Pune, ,Maharshtra, India.

(Email : jeevan.nagarkar@siib.ac.in)
Over the years, corporate social responsibility has

Dr. Jeevan Nagarkar Symbiosis Institute of International Business,

It is relevant to mention here that the Brundtland commission in 1987 coined the term sustainable development with a heavy contextualisation of integrating industrial and business growth with societal involvement. Post 1990s the Earth Summit at Rio further reinforce the idea of including social equity as a dimension of efficiency and productivity. It is only in the decade of 2000s that various global organisation began to understand the crucial link between industrial efficiency through the lens of societal responsibility. Understandably, regulatory frameworks both mandatory and voluntary were established to provide a platform for various business entities to share their experience on social responsibility through various approaches. Voluntary standards like the Global reporting initiative, SA 8000, Sustainability indices suggested that the triple bottom line concept (Elkington,1997) must be a core element of social sustainability.

In a growth oriented economy, company performance is often measured primarily through financial parameters like stock prices, profit and loss, revenue generation rather than non financial parameters. However, increasingly companies have started to consider engagements with stakeholders and society as major concerns (Andriof et.al.,2017) towards boosting corporate goals and performance.

The recent emergence of voluntary social standards have helped to understand the linkages between company performance, earnings (Moratis and Egmond 2018) and delivering on social responsibility projects. Friedman (1970) and Freeman (1984) proposed the theory of agency and stakeholders, where they emphasized on CSR as a selfserving behavior on the part of managers, who should make their policies to satisfy numerous constituents in society. Hart (1995) focused on environmental social responsibility for the first time. Hart suggested that firms with competitive advantage can constitute for the environmental sustainability initiatives. Baron (2001) suggested the use of CSR to attract socially responsible consumers is more strategic. Various CSR initiatives is now seen as a competitive business strategy arising from performance and stakeholder pressures.

This has implication on the Indian CSR sector where companies have been mandated to spend two percent of their profits on CSR related projects. Companies are devising their own policies for CSR since it has become mandatory. The policies are mostly seen to be in line with the company's own strength and area of operations. This is a major challenge since these company specific areas may not 
be in sync with the national developmental agenda. Since 2013 nearly Rs 10,000 crores have been utilised by corporate entities through various initiatives (PWC, 2018). However, it is important to mention here that sectoral involvement of infrastructure sector projects through targeted CSR spending has been limited.

In India historically, philanthropy and corporate social responsibility has always been an integral element of business and industry. However, in recent times, the maturing of CSR has often been viewed with criticism for its ineffectiveness in societal transformation. The CSR Act promulgated in 2013 by the Government of India was one of the first steps towards initiating social responsibility initiatives including evolving a structured CSR framework.

The needs of the Indian economy are multifaceted and companies will find diverse areas to spend their CSR money on. This is one of the reasons why there are $n$ number of initiatives targeted in different directions (Mitra et al.,2018). identifying right projects and being able to implement those project is a key challenge in Indian context (Kapoor et al.,2017). While there were several instances of corporate entities sharing their experiences of involving social responsibility as a key element of wellbeing, this was often negated by the lack of visible social transformation on ground. Sectors like solid waste management particularly in urban cities remains a challenge for any developing country. The cost of collection of this waste and disposal is very high (Guerrero et al.,2013). The development of necessary infrastructure for solid waste management in developing countries is very essential, there have been cases where PPP model is used for this purpose (Ahmed and Ali, 2004). If CSR funds of companies is used for creation of such infrastructure it will not only streamline the expenditure to solving a particular problem faced by Indian cities today but it will have a concrete mechanism created for years to come. Over the past five years this has meant that several interesting facets for providing a tangible results for social responsible projects. India's tryst with regulated CSR has grown over the years (PWC,2018) with several organisations implementing social projects which were also aligned with national/ Government missions and global missions like SDG schemes.

India lacks in basic infrastructure which can help the nation progress in a sustainable manner. It has been observed that India needs almost USD 1 Trillion to develop infrastructure for its current development needs. The SDGs which include sustainable cities and communities require basic infrastructure of roads and other urban facilities but it also requires waste management infrastructure which can sustain healthy life for urban population. It has been noted that Indian cities lack this infrastructure and improper dumping of waste is creating environmental problems in India (Kumar S. et al. 2017). There is a urgent need to look at this problem. There have been private initiatives in this regard in India like Adar Poonawalla group trying to create infrastructure for scientific collection of solid waste in Pune City. Though the initiative deserve a mention but such fragmented and isolated efforts are not enough to solve this problem at national level. There has to be coordinated and targeted efforts from Indian central government and corporates in this direction. In India, companies with a net profit of more than US\$ 750,000 (Rs 5 crores) in one financial year must spend at least 2 percent of their average net profits in the last 3 years (before taxation) under the Corporate Social Responsibility Initiative. Currently, there is limited mechanism in India for monitoring or regulation of CSR expenditure beyond the CSR Act,2013. The board of a company is, however, responsible for reporting its CSR expenditure on its website and annual report. Companies can also choose to use a CSR consultant to administer their CSR portfolio. As mentioned, earlier companies are doing their bit in every area of their interest. It is therefore suggested that the entire pool of CSR fund is collected centrally, a committee of corporate CEO and Government official finalizes on three major areas where this CSR fund can be utilized for next five years and a solid and sustainable infrastructure is created on ground which will sustain the activity for long term. The broad areas could be the major areas where government has not been able to create an impactful policy.

The present study is an attempt to understand the involvement of the industrial sector companies in CSR projects in the context of targeted CSR budget spending. This has implications as the nation moves towards a development and infrastructure oriented growth economy. The Indian infrastructure space is expected to get a significant boost in the next few years with investments worth nearly 50 trillion Rupees in key sectors like urban transport, railways, renewable energy, highways etc. The rapid pace of implementing large infrastructure developmental projects is therefore an indicator of industry's performance in the sector.

This paper has analyzed the CSR expenditure of top market cap companies in last four years and seeks to analyse the relationship between company CSR budgets and corresponding CSR spending within key industry sectors. The results show that CSR expenditure is either spent on areas of convenience or it is too fragmented to create any national level impact which will create long term solutions to the problems defined by SDGs. The study also suggests a governance model for effective use of CSR budgets for promoting infrastructure development.

\section{METHODOLOGY}

In the Indian context, the shift from voluntary to mandatory CSR spend has been very new and hence research on CSR related aspects has been restricted to using reports available through the disclosures. To analyze the behavior and also to understand the trend it is important to study the CSR spend of organizations across sectors and year on year till date. The present research has been conducted on the top 120 market listed companies with focus on areas of engagement of CSR from the perspective of governance and responsibility of the stakeholders on CSR governance. The study attempts to analyze the CSR expenditure of in last four years, areas of CSR expenditure with a sample size of top 120 market cap companies in the Indian context. For the purpose of data collection, 
information on budgetary expenditure, CSR budgets was collected from the annual reports available on the company websites for the financial years 2014,2015, 2016, 2017 and 2018 as well as from online financial platforms like Bloomberg.

The key objectives of the study included:

1. To explore the pattern of CSR spend by the top 120 stock market listed companies in various thematic areas

2. To propose a theoretical model for CSR funds utilization in areas such as infrastructure building for national missions such as SWACH Bharat, Ayushman Bharat, Smart City Initiatives etc.

\section{RESULTS}

Mandatory regulation by government for $2 \%$ CSR funds utilization as per the CSR policy guidelines does not mandate specific thematic areas where the funds are to be utilized. There have been guidelines about broader areas and hence give flexibility for the organizations to use the CSR funds in activities directed towards development of community as well as for their businesses. Traditionally, organisations have focused on education and skill development from perspective of strengthening primary and secondary education. Environment, health, rural development and women empowerment related activities also have been preferred by businesses as they give more visibility and help economic development.

To understand the CSR funds utilization by the top 120 market cap listed companies various authentic sources such as Annual reports of the companies through official websites and Bloomberg database were used for data collection. Compilation of data to study the areas of CSR spend, trend of CSR utilization and non-utilized funds for the financial years 2014 till 2018 was carried out. The results and data analysis have been depicted through tables and graphs in the following discussion.

\section{Sectorwise Companies in \%}

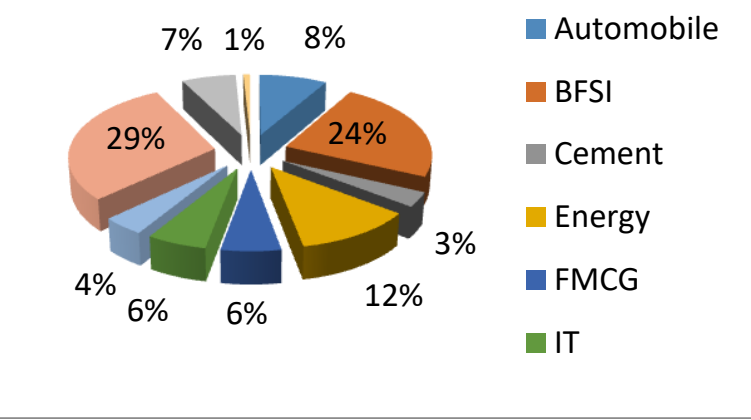

Fig 1. Distribution of companies' sector wise

The organizations under study were categorised into sectors such as Automobile, Cement, Energy, BFSI, FMCG, Pharma, Energy, IT, Oil and Gas and others (Entertainment, Health care, manufacturing etc). BFSI sector constitutes the maximum number of companies $(24 \%)$ followed by Energy $(12 \%)$ and the lowest in retail $(1 \%)$.

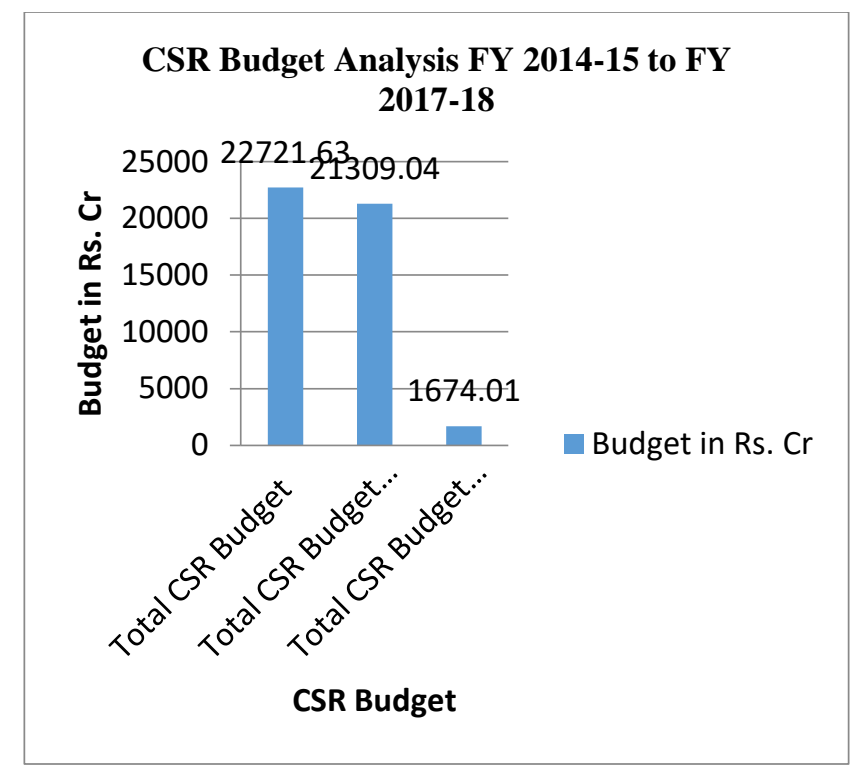

Fig 2. CSR Budget Analysis of 120 market cap companies

Figure 2 depicts the total CSR funds budgeted over the FY 2014-15 to $2017-18$ by all the top 120 companies under study. It can be seen that $93 \%$ of the total budgeted CSR funds were utilized in various projects and merely $7 \%$ of the funds were unutilized. The un utilized funds were reported in their annual reports with explanation and reasons for noncompliance. It has been a trend by some companies not to comply with the CSR Act and mere report and taking cognizance of the same, Ministry of Corporate Affairs has started the process of identification and has been sending the scrutiny notices to the faltering companies. In the present study analysis of the utilisation and non-utilisation of CSR funds by the companies considered for study was carried out for 4 financial years FY2014-15 to FY 2017-18. Fig 3 shows the trend of CSR funds utilisation over the years.

\section{CSR Funds Utilised Vs Un Utilised}

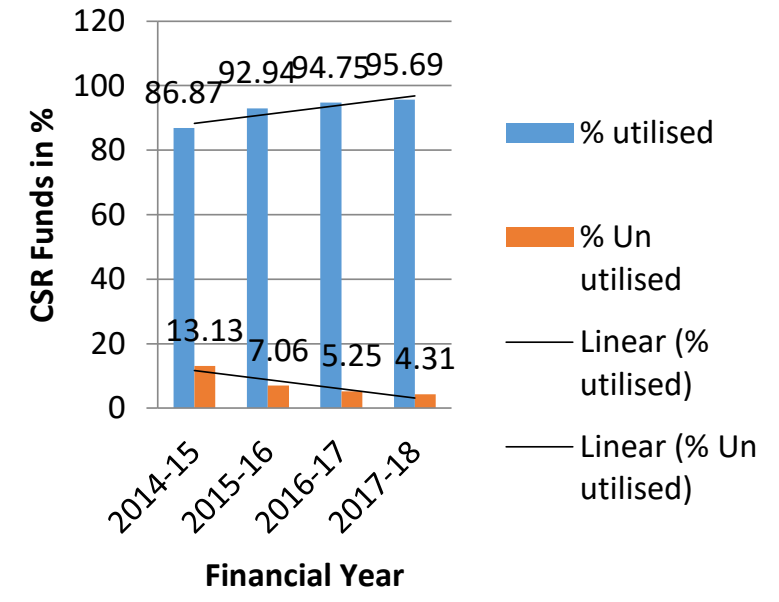

Fig 3. Comparative Analysis of CSR Funds Utilisation 
Post implementation of CSR mandate there has been gradual increase in the utilization of funds from $87 \%$ to $96 \%$ and hence decrease in non-utilization from $13 \%$ to mere $4 \%$. Positive trend in the utilsation and negative trend in non-utilisation indicates that companies have been participating actively in CSR projects. In order to comply with the regulations and taking advantage of the freedom in choosing the areas of funds utlisation, companies decide the projects and carry out the work with their workforce or in many cases entrust the responsibility to Non Profit organisations. But there would be supervision of the projects by their CSR committee having a member who has to be one of the directors of the company.

In the current study five key areas which have been indicated in the CSR guidelines by Ministry of Corporate Affairs were considered to understand the focus areas of CSR funds utilization by the companies under study belonging to various sectors. Education and Skill Development, Environment related areas, Rural Development, Women Empowerment and Health \& Sanitation were considered as the key areas of CSR Projects. Table 1 to Table 5 shows the \% of CSR funds utilization in 4 financial years post CSR Act implementation.

Emphasis and global thrust on environment related areas has led to organisations involvement in activities such as tree plantation, rain water harvesting etc. In the current study, BFSI and FMCG sectors have been the major contributors in Environment related projects

Table-I: CSR funds in Environment

Sectorwise CSR funds utilisation in Environment related areas in \% FY14-15 to FY17-18

\begin{tabular}{|l|l|l|l|l|}
\hline Sector & $\begin{array}{l}\text { FY14_ } \\
15\end{array}$ & $\begin{array}{l}\text { FY15 } \\
16\end{array}$ & $\begin{array}{l}\text { FY16_ } \\
17\end{array}$ & $\begin{array}{l}\text { FY17_ } \\
18\end{array}$ \\
\hline $\begin{array}{l}\text { Automob } \\
\text { ile }\end{array}$ & 2.15 & 2.06 & 1.96 & 2.07 \\
\hline BFSI & 26.03 & 16.91 & 40.61 & 16.82 \\
\hline Cement & 1.02 & 1.87 & 1.88 & 2.11 \\
\hline Energy & 12.47 & 13.37 & 11.69 & 11.37 \\
\hline FMCG & 19.97 & 18.36 & 15.52 & 15.60 \\
\hline IT & 5.78 & 6.40 & 6.17 & 6.35 \\
\hline NBFC & 0.20 & 0.22 & 0.18 & 0.19 \\
\hline $\begin{array}{l}\text { Oil and } \\
\text { Gas }\end{array}$ & 10.17 & 8.01 & 7.13 & 6.88 \\
\hline Others & 11.61 & 11.82 & 17.74 & 18.17 \\
\hline Pharma & $\mathbf{5 . 7 8}$ & $\mathbf{5 . 5 7}$ & $\mathbf{5 . 3 1}$ & 4.90 \\
\hline Telecom & 1.65 & 1.60 & 1.50 & 1.45 \\
\hline
\end{tabular}

The $\%$ of contribution by BFSI varying between 26 to 40 $\%$,whereas by FMCG ranging in range $15 \%$ to $20 \%$. The figures indicate that the focus and funds vary, hence may not be involved in the same projects over the years and may not help in sustainable development.

Table-II: CSR funds in Education

Sectorwise CSR funds utilisation in Education and Skill development areas in \% FY14-15 to FY17-18

\begin{tabular}{|l|l|l|l|l|}
\hline Sector & FY14_15 & FY15_16 & FY16_17 & FY17_18 \\
\hline Automobile & 2.89 & 2.62 & 2.34 & 3.67 \\
\hline BFSI & 18.9 & 18.71 & 21.04 & 13.29 \\
\hline Cement & 1.3 & 1.59 & 2.22 & 2.08 \\
\hline Energy & 9.95 & 10.75 & 11.91 & 10.47 \\
\hline FMCG & 8.56 & 8.59 & 7.76 & 7.62 \\
\hline IT & 8.05 & 8.57 & 8.12 & 8.44 \\
\hline NBFC & $\mathbf{0 . 2 2}$ & $\mathbf{0 . 2 1}$ & $\mathbf{0 . 1 8}$ & $\mathbf{0 . 1 8}$ \\
\hline $\begin{array}{l}\text { Oil and } \\
\text { Gas }\end{array}$ & $\mathbf{8 . 0 1}$ & 8.58 & 7.15 & 8.13 \\
\hline Others & 14.22 & 13.07 & 15.32 & 21.97 \\
\hline Pharma & 6.14 & 5.93 & 5.27 & 5.12 \\
\hline Telecom & 1.89 & 2.33 & 1.66 & 1.86 \\
\hline
\end{tabular}

BFSI and Energy sectors have been the major contributors in Education and skill development related projects. The $\%$ of contribution by BFSI varying between $13 \%$ to $21 \%$, whereas by Energy ranging in range $10 \%$ to $12 \%$. Education and skill development projects have found prominence for funds utlisation amongst all sectors. Table 2 shows that almost all the sectors have been involved in the education projects and more or less consistent in terms of percentage utilization. The figures indicate that the focus and funds have been consistent ,hence may be involved in the same projects over the years and may help in sustainable development. Education being the prime focus by national as well as state governments already gets large funding and involvement of CSR funds should strengthen the area. But it is often seen that these projects also engage the distribution of education related materials or uniforms / bags etc.

Table -III : CSR funds in Women Empowerment projects

Sectorwise CSR funds utilisation in Women Empowerment related areas in \% FY14-15 to FY1718

\begin{tabular}{|l|l|l|l|l|}
\hline Sector & $\begin{array}{l}\text { FY14_1 } \\
\text { FY15_1 }\end{array}$ & $\begin{array}{l}\text { FY16_1 } \\
6\end{array}$ & $\begin{array}{l}\text { FY17_1 } \\
8\end{array}$ \\
\hline $\begin{array}{l}\text { Automobil } \\
\text { e }\end{array}$ & 2.3 & 2.69 & 2.31 & 2.29 \\
\hline BFSI & 18.11 & 17.87 & 18.62 & 18.34 \\
\hline Cement & 2.71 & 2.61 & 2.1 & 1.77 \\
\hline Energy & 15.48 & 15.45 & 13.86 & 14.38 \\
\hline FMCG & 13.34 & 11.58 & 11.52 & 10.73 \\
\hline IT & 7.38 & 8.66 & 10.97 & 11.81 \\
\hline NBFC & 0.41 & 0.49 & 0.42 & 0.46 \\
\hline $\begin{array}{l}\text { Oil and } \\
\text { Gas }\end{array}$ & 9.35 & 8.92 & 7.92 & 7.92 \\
\hline Others & 18.81 & 20.37 & 22.3 & 22.44 \\
\hline Pharma & 9.3 & 8.56 & 7.5 & 7.28 \\
\hline Telecom & 2.8 & 2.8 & 2.48 & 2.57 \\
\hline
\end{tabular}


Development of society without involvement and empowerment of women seems impossible as they drive every aspect of society. It has been a necessity and importance that women are empowered in various ways for

Table-IV: CSR funds in Rural development

\begin{tabular}{|c|c|c|c|c|}
\hline \multicolumn{5}{|c|}{ Sectorwise CSR funds utilisation in Rural } \\
Development related areas in \% FY14-15 to FY17- \\
\hline Sector & $\begin{array}{c}\text { FY14_1 } \\
5\end{array}$ & $\begin{array}{c}\text { FY15_1 } \\
6\end{array}$ & $\begin{array}{c}\text { FY16_1 } \\
7\end{array}$ & $\begin{array}{c}\text { FY17_1 } \\
8\end{array}$ \\
\hline $\begin{array}{c}\text { Automobi } \\
\text { le }\end{array}$ & 3.7 & 3.27 & 4.4 & 3.41 \\
\hline BFSI & 15.7 & 15.79 & 17.68 & 21.71 \\
\hline Cement & 4.05 & 3.31 & 2.89 & 3.19 \\
\hline Energy & 22.56 & 20.97 & 20.49 & 19.78 \\
\hline FMCG & 6.41 & 5.13 & 5.86 & 5.47 \\
\hline IT & 8.12 & 7.11 & 7.81 & 8.81 \\
\hline NBFC & 0.48 & 0.49 & 0.56 & 0.54 \\
\hline Oil and & & & & \\
Gas & 11.05 & 22.11 & 13.95 & 13.3 \\
\hline Others & 17.29 & 12.86 & 16.04 & 14.11 \\
\hline Pharma & 8.04 & 6.76 & 7.85 & 7.24 \\
\hline Telecom & 2.59 & 2.21 & 2.47 & 2.46 \\
\hline
\end{tabular}

sustenance and participation in different fields like finance, social, culture, law, Industry and politics. The recognition by the corporate world for women empowerment in every possible functional areas results in their efforts through CSR projects with focus on women. The current study also found that almost all sectors have been emphasizing on women empowerment projects. BFSI sector where in women participation in the workforce traditionally has been more also spends maximum in women empowerment with around $18 \%$ consistently in the years 2014-2018. Energy sector's spend has been in the range of $13 \%$ and $15 \%$. FMCG's spend range remains between $11 \%$ to $13 \%$. Table 3 summarizes the CSR spend in women empowerment in various sectors.

India, a true representation of rural as well as urban population needs more focus on rural development which as it indicates social transformation and economic betterment of people. Better participation of businesses in the rural development programmes helps in decentralized approach for planning, better enforcement of projects will help urbanrural divide by upgrading the standard of living of people in rural areas. Table 4 summarizes the pattern of CSR spend by various sectors in 4 years post CSR Act implementation. Energy Sector has been spending the maximum (between $20 \%$ to $22 \%$ ), followed by BFSI (between $16 \%$ to $22 \%$ ) and then the Oil and Gas sector (between $11 \%$ to $22 \%$ ).

Though the other sectors also have contribution, but not very significant or consistent in developing rural India.
Table-V: CSR funds in Health and sanitation Sectorwise CSR funds utilisation in Health and Sanitation areas in \% FY14-15 to FY17-18

\begin{tabular}{|l|r|r|r|r|}
\hline \multicolumn{1}{|c|}{ Sector } & \multicolumn{1}{c|}{$\begin{array}{r}\text { FY14 } \\
\text { Automobil }\end{array}$} & $\begin{array}{r}\text { FY15_1 } \\
\text { e }\end{array}$ & $\begin{array}{r}\text { FY16_1 } \\
\text { e }\end{array}$ & $\begin{array}{r}\text { FY17_1 } \\
\text { 8 }\end{array}$ \\
\hline BFSI & 23.96 & 2.41 & 3.08 & 3.4 \\
\hline Cement & 2.14 & 2.94 & 3.09 & 2.97 \\
\hline Energy & 12.26 & 20.24 & 17.16 & 21.6 \\
\hline FMCG & 13.84 & 12.15 & 13.62 & 14.22 \\
\hline IT & 6.33 & 6.67 & 7.26 & 8.5 \\
\hline NBFC & 1.14 & 1.08 & 1.38 & 1.79 \\
\hline Oil and & & & & \\
Gas & 9.42 & 6.9 & 7.15 & 8.8 \\
\hline Others & 13.29 & 12.28 & 12.11 & 14.79 \\
\hline Pharma & 7.68 & 8.2 & 8.84 & 8.3 \\
\hline Telecom & 2.32 & 2.05 & 2.8 & 1.72 \\
\hline
\end{tabular}

Health and sanitation related projects focused through the CSR spend helps in building healthy population of the nation. Nonexistent or poor public health care system in India requires involvement and investment from many stakeholders. The funds propelled just alone by government have been insufficient owing to the large population requires a helping hand by business houses also. Responsibility of corporates has become essential to deliver healthcare systems through projects focused at health care and sanitation promoting the community at large. Table 5 summarizes the CSR spend in health and sanitation projects. BFSI sector contributes the maximum in the range $13 \%$ to $24 \%$, Energy being the second with spend range between $12 \%$ to $21 \%$ and FMCG being third with $12 \%$ to $14 \%$.

From the analysis carried out in the current study on the CSR budget and respective spend on the top 120 market cap listed companies it can be seen that BFSI, FMCG and Energy sector have been the front runners CSR spend across 5 key areas identified. An interesting fact which can be seen from the analysis has been that there is not much consistency in the percentage spend. Companies decide on their own the areas of CSR spend and as they are not required to measure the impact of any of these projects, many a times the huge money spend does not necessarily yield the required benefit. With the background of CSR mandate from voluntary participation, reluctance to active participation phase in the last 5 years, it can be further discussed and emphasized how can the CSR funds usage be more focused and impactful. Authors in the discussion part discuss the pre and post CSR act and propose a model for CSR funds utilization by integration with the national missions.

\section{DISCUSSION}

The Companies Act of 2013 under section 135(1) with the provision under Corporate Social Responsibility 
mandates every company having net worth of Rupees five hundred crore or more, or turnover of Rupees one thousand

crore or more or a net profit of Rupees five crore or more during any financial year shall constitute a Corporate Social Responsibility Committee of the Board consisting of three or more directors, out of which at least one director shall be an independent director. With mandated CSR spend aiming at instilling a sense of responsibility amongst the companies towards the society, business organizations have an opportunity to influence and be a responsible stakeholder in the community development. In the perspective of larger societal picture corporate entities need to take up a larger share of responsibility not just by paying taxes. With a proposition to decentralize the process of inclusive development by the government with CSR guidelines was not acknowledged by the corporate sector very well with lot of opposition of this clause of CSR mandatory from voluntary. In spite of divisive voices amongst the corporate community there has been a consensus on a larger front and the companies have been undertaking diverse range of projects in areas such as education, environment, health and sanitation, rural development, women empowerment etc. This has resulted in a total average overall expenditure of more than Rs. 1000 crore every year from 2014-2018 towards various social welfare projects as per the authentic data from National CSR Portal, Ministry of Corporate Affairs.

In the current study, CSR data of 120 top market cap listed companies was analysed in order to understand the nature of CSR expenditure. The results indicated that that education and environment have been receiving the highest expenditure from the companies with FMCG and the BFSI sector being the major contributors. At the national level as well as state level (since education is a subject of state list) governments have undertaken many projects like Sarva Shiksha Abhiyan, Rashtriya Ucchatar Shiksha Abhiyan, establishing Kendriya Vidyalayas, Navodaya Vidyalayas and many more. With the global thrust on environment projects such as Clean Ganga, biodiversity conservation and afforestation, pollution Control, waste Management etc. also have got due concern and attention from the government as well as business organizations. The data analysis in the study shows that the approach of many companies has been merely to ensure compliance towards the statutory obligation instead of a sustainable and proactive efforts towards social welfare. Crores of rupees available and spent through the CSR budget have been materialised into high budgeted expenditure and lower actual utilisation displaying no impact of these funds on the societal development. Many organisations do not comply with the guidelines and hence face prosecution which has been reported by Economic time published in December 2018 in the Economic Times that 284 companies were on the verge of facing prosecution for non-compliance of CSR.

It has been observed from the data analysis of the top 120 companies CSR budget spending pattern, that the CSR spend on the education and environment sector have been very prominent across the sectors. There has been efforts to engage in these activities but with varied spend and diverse activities, the sustainability of the efforts has been questionable. Indeed the business organizations have engaged in CSR as compliance but need a focused approach with involvement of all the stakeholders for mutual benefit. Education and environment programs certainly help in strengthening the nation by development of young generation and also conservation of environment. Lack of sustained efforts in the same areas over the years through the involvement and investment of the business organisations through their CSR programs both in rural and urban India result in discrete activities. Post 2013 after the CSR Policy implementation, it has been seen that organisations comply but also need a focused approach. Business organisations should not be alone held responsible for carrying CSR activities as that is not their prime concern. Necessity of the impactful execution needs involvement of all stakeholders with focused approach of concentrating not only on select areas such as education environment related activities but also important areas such as infrastructure development for national missions such as Ayushman Bharat, Swachh Bharat etc.

With significant changes being adopted by following a model approach in the execution and compliance of the CSR, the government and businesses can attempt to realise the honest objective of CSR clause in the Companies Act, 2013. Many stakeholders exist in this process but the paper outlines important stakeholders and with their involvement proposes the model which can be used for CSR projects as depicted by Fig 5 and 6 .

\section{Proposed model}

The working of the model has the following salient features. The proposal calls for establishment of a National CSR Committee under the Ministry of Corporate Affairs, Government of India with eminent members representation from the government, social sector and the corporate world. . It is recommended that the task and responsibility of the committee would be -

1. Brainstorm and finalize the CSR project strategy for a period of 2-3 years with inputs from all stakeholders keeping in mind the national mission as priority.

2. Pool the unutilized CSR funds and also a predefined $\%$ of CSR funds from business organisations every year.

3. Decide the roles and responsibilities of different stakeholders with a blue print of projects execution roadmap.

4. Share the project execution roadmap with timelines and a clear stated objective for implementation and achievement with stakeholders

5. Monitor the projects and carry out the social and economic impact assessments of the projects. .

6. Review and revise the focus on projects under the aegis of national Missions every two to three years. 


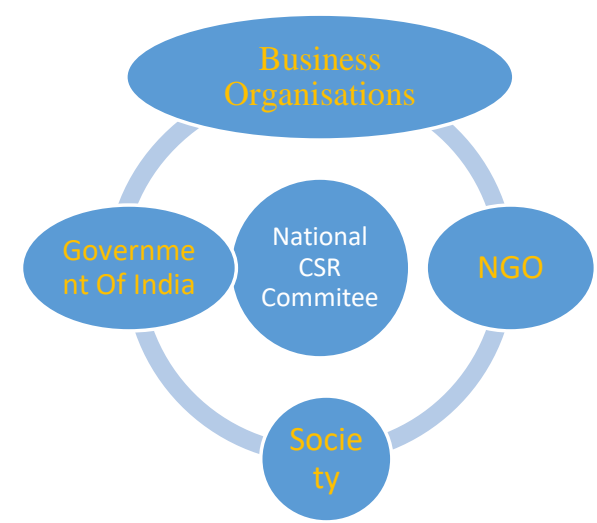

Fig 4 . Stakeholders in National CSR Committee

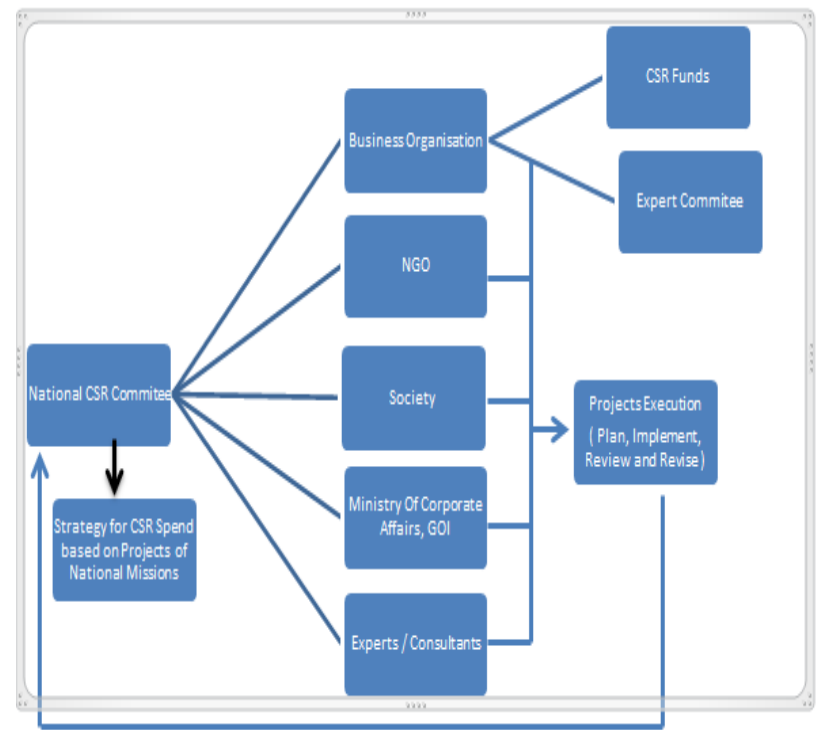

Fig 5. Integrated Model for CSR Projects for National Mission

The proposed model is expected to bring real impact on the society and fulfilling the expectations of various stakeholders. The focused approach, review and plan would lead to a situation which would help in nation building and showing the results motivating the businesses to participate positively in the CSR activities as there would be shared approach.

\section{REFERENCES}

1. Andriof, J., Waddock, S., Husted, B., \& Rahman, S. S. (2017), Unfolding stakeholder thinking: theory, responsibility and engagement. Routledge.

2. Ahmed, S. A., \& Ali, M. (2004). Partnerships for solid waste management in developing countries: linking theories to realities. Habitat international, 28(3), 467-479.

3. Baron, D. P. (2001). Private politics, corporate social responsibility, and integrated strategy. Journal of Economics \& Management Strategy, 10(1), 7-45.

4. Elkington, J (1997). Accounting for the triple bottom line. Measuring Business Excellence, 2(3),18-22.

5. Friedman, M. (1970). A Friedman doctrine: The social responsibility of business is to increase its profits. The New York Times Magazine, 13(1970), 32-33.

6. Freeman, R. E. (2010). Strategic management: A stakeholder approach. Cambridge university press.

7. Guerrero, L. A., Maas, G., \& Hogland, W. (2013). Solid waste management challenges for cities in developing countries. Waste management, 33(1), 220-232.
8. Hart, S. L. (1995). A natural-resource-based view of the firm. Academy of management review, 20(4), 986-1014.

9. Mitra, N., Mukherjee, D., \& Gaur, A. (2018). Mandated Corporate Social Responsibility in India: Opportunities, Constraints, and the Road Ahead. Constraints, and the Road Ahead (December 1, 2018).

10. Moratis L and VanEgmond M (2018) Concealing social responsibility? Investigating the relationship between CSR,earnings management and the effect of industry through quantitative analysis. International Journal of Corporate Social Responsibility 3:8, 1-13.

11. Kapoor, G. K., \& Dhamija, S. (2017). Mandatory CSR Spending-Indian Experience. Emerging Economy Studies, 3(1), 98-112.

12. Kumar, S., Smith, S. R., Fowler, G., Velis, C., Kumar, S. J., Arya, S., Rena, Kumar R and Cheeseman, C. (2017) Challenges and opportunities associated with waste management in India. Royal Society Open Science, 4(3), 160764

\section{AUTHORS PROFILE}

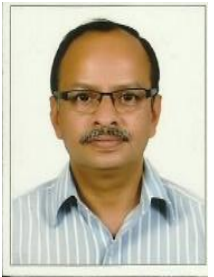

Dr. Prakash Rao has 35 years of experience in the field of energy and environment management with interests in climate change and energy and sustainable development sectors. He holds a Ph.D. from the University of Bombay and has coordinated several multidisciplinary projects ranging from natural resources to climate change and energy. $\mathrm{He}$ has led the Climate Change and Energy Programme at WWF-India for nearly ten years, coordinating its global research, energy policies and community action. Has published around 86 research papers,notes and book chapters in peer reviewed international journals and books including several articles in magazines and the media and undertaken several consultancies and contributes in an advisory capacity to the corporate sector on environmental sustainability issues. He is also the Deputy Editor of the International Journal of Agricultural Resources, Governance and Ecology(Inderscience Publishers).Dr Rao has published four books including one with Prof. S. K. Dash of Indian Institute of Technology,Delhi on Assessment of Climate Change in India and mitigation policies and a book on Water and climate change with IGI Global Publishers, USA.

He is currently the Deputy Director,Professor and Head of the Energy and Environment Programme at Symbiosis Institute of International Business (SIIB), a constituent of Symbiosis International University, Pune. $\mathrm{He}$ is also a certified Sustainability Assurance Practitioner from Accountability, UK and the GRI Reporting Sustainability standards

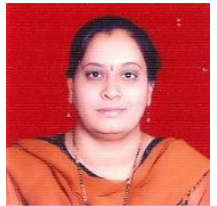

Dr.. Viraja P. Bhat has more than 18 years of experience which comprises of industry as well as academics. She holds an engineering degree in electronics and communcication from Karnataka University and master degree in management from Pune University. She has completed her doctoral degree (Ph.D ) from Symbiosis International University in the area of Electronic Waste Management. Her experience comprises of both industry and academia in the area of Software development, Project management, ERP. She is a SAP TERP 10 certified trainer. She has good understanding of business analytics, Business processes, Business process Reengineering, ERP, Data Analysis, RDBMS, Programming languages ,Requirement Analysis , IT strategy development and implementation.

She works as an HOD-IT and Assistant professor at Symbiosis Institute Of International Business, Pune. She conducts training program for SAP University Alliance and data analysis using excel. MS Project. She has a very keen interest in the area of corporate social responsibility and she has been mentoring the students of SIIB for the ISR initiative( Kshitij) for more than 10 years, which has been proactive in various projects to develop the community. She has published papers and chapters in the area of electronic waste management, sustainability and corporate social responsibility. 
Dr. Jeevan Nagarkar is an Assistant Professor at the Symbiosis Institute of International Business, Pune, a constituent of Symbiosis International (Deemed University). Dr Nagarkar obtained his Master's Degree in Economics from Fergusson College Pune. He has an MBA in Finance specialisation and a PhD in Economics. He has 12 years of teaching Experience. His research areas include macroeconomics, financial markets equity analysis and CSR initiatives. 